\title{
Regression of the corpora lutea in sheep in response to cloprostenol is not affected by loss of luteal oxytocin after hysterectomy
}

\author{
E. L. Sheldrick and A. P. F. Flint \\ A.R.C. Institute of Animal Physiology, Babraham, Cambridge CB2 4AT, U.K.
}

\begin{abstract}
Summary. Concentrations of oxytocin in corpora lutea were reduced from 1706 to less than $15 \mathrm{ng} / \mathrm{g}$ wet wt after hysterectomy in sheep during the oestrous cycle. Hysterectomy also blocked the appearance of raised levels of oxytocin in ovarian and jugular venous plasma caused by cloprostenol. Administration of cloprostenol to hysterectomized ewes resulted in luteal regression, which occurred as rapidly as in intact animals. Therefore oxytocin in the corpus luteum during the oestrous cycle is unlikely to be involved in intraluteal events mediating prostaglandin-induced luteolysis.
\end{abstract}

\section{Introduction}

The high concentration of oxytocin in the ovine corpus luteum (Wathes \& Swann, 1982; Flint \& Sheldrick, 1982) may be involved in the process of luteal regression in 2 ways. Luteal oxytocin may act systemically to stimulate uterine secretion of prostaglandin (PG) F-2 $\alpha$, which is luteolytic (see Flint \& Hillier, 1975). The release of oxytocin from the corpus luteum in response to the luteolytic PGF- $2 \alpha$ analogue, cloprostenol, and the secretion of PGF- $2 \alpha$ caused by oxytocin, suggest that positive feedback may operate between the ovary and the uterus to ensure the rapid progress of luteal regression (Flint $\&$ Sheldrick, 1983). In addition to a systemic action, oxytocin may also have a local luteolytic effect on, or within, the luteal cells. Adashi \& Hsueh (1981) have demonstrated inhibition by several neurohypophysial hormones, including oxytocin, of gonadotrophin-stimulated steroid synthesis by isolated rat Leydig cells in culture, and Tan, Tweedale \& Biggs (1982a, b) have observed similar effects with oxytocin, using bovine and human luteal cells. We have found that when luteal function is prolonged by hysterectomy (Wiltbank \& Casida, 1956) the concentration of oxytocin in the corpus luteum is markedly reduced, and have used this response to test whether luteal oxytocin has a local lytic effect by determining rates of regression of the corpora lutea in response to cloprostenol in intact and hysterectomized sheep.

\section{Materials and Methods}

Animals. Parous Clun Forest ewes were taken from the flock at Babraham between November 1981 and February 1982. Dates on which oestrus occurred were determined by running the ewes with a raddle-bearing vasectomized ram; none of the animals received any treatment to synchronize or induce oestrous cyclicity before experimentation. Mean oestrous cycle length before treatment in the flock was $16 \cdot 5 \pm 0 \cdot 1$ days $(n=63)$; all ewes had at least 2 recorded oestrous cycles before treatment. 
On Day 6 or 7 after oestrus (day of oestrus $=$ Day 0 ) 9 animals were hysterectomized via a midventral abdominal incision, using aseptic techniques. Anaesthesia was induced with pentobarbitone sodium and maintained after endotracheal intubation with halothane in oxygen. After ligating first the uterine arteries, followed by the uterine veins, a silk ligature was tied round the uterocervical junction and the uterus and oviducts were removed. Abdominal incisions were closed in 2 or 3 layers using polyglycolate sutures (Dexon; Davis \& Geck Ltd, Gosport, U.K.). In 4 shamhysterectomized ewes, a single silk suture was tied in the wall of the uterus close to the uterocervical junction, without occluding the uterine lumen, and left in situ.

Jugular venous blood samples were taken by venepuncture daily (usually between 14:00 and 15:00 h) from the sham-operated and hysterectomized ewes, beginning at the oestrus before surgery. Progesterone concentrations measured in these samples confirmed that luteal function was prolonged in all the hysterectomized ewes (Text-fig. 1). For more frequent sampling from the jugular vein (when samples were taken during the $10 \mathrm{~h}$ before and $40 \mathrm{~h}$ after administering cloprostenol) catheters were inserted under local anaesthesia (Seldinger, 1953) at least $24 \mathrm{~h}$ before experimentation. Ovarian venous blood samples were also taken via polyvinyl catheters from 4 intact and 4 hysterectomized ewes in which anaesthesia was induced with pentobarbitone and maintained with halothane in $\mathrm{O}_{2}$. In this experiment blood samples were collected 10,5 and 2 min before the i.m. administration of $125 \mu \mathrm{g}$ cloprostenol (Estrumate: ICI, Macclesfield, U.K.) and 1, 5, 10, 15, 20, 30 and 40 min after treatment. All blood samples were collected into heparinized tubes and plasma was stored at $-20^{\circ} \mathrm{C}$ before assay.

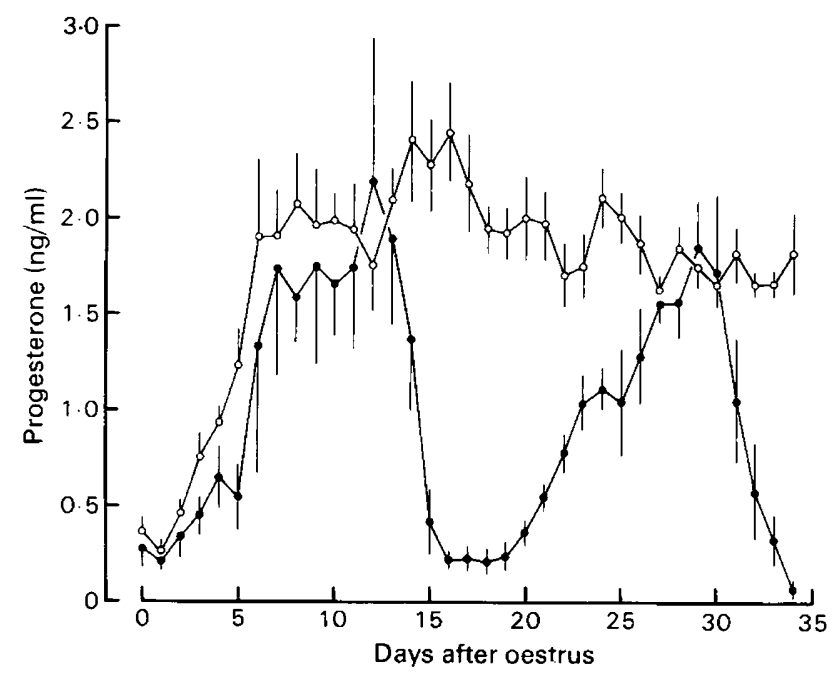

Text-fig. 1. Concentrations of progesterone in jugular venous plasma from non-pregnant intact $(O)$ and hysterectomized $(O)$ ewes. Values are means; vertical bars indicate s.e.m. Hysterectomy was performed on Day 6 and 7 after oestrus; control animals were sham operated between Days 6 and 9. Behavioural oestrus was not observed after hysterectomy; sham-operated animals returned to oestrus on Days $16(\mathrm{~N}=1)$ or $17(\mathrm{~N}=3)$ and cycled normally thereafter.

\section{Extraction of oxytocin from corpus luteum}

Samples of corpora lutea $(0 \cdot 2-1 \cdot 0 \mathrm{~g})$ were taken from 13 untreated intact sheep between Days 8 and 14 of the cycle; from 5 cloprostenol-treated intact sheep between Days 11 and 14; from 3 untreated hysterectomized sheep 28, 53 and 56 days after last oestrus; and from 6 cloprostenoltreated hysterectomized ewes between 53 and 83 days after oestrus. Tissue was extracted by homogenization in $10 \mathrm{ml} \mathrm{1 \%}$ acetic acid, after adding $\left[{ }^{3} \mathrm{H}\right]$ propionyl oxytocin $(80000$ d.p.m.; prepared as 
described by Flint \& Sheldrick, 1983) to allow calculation of extraction losses. Homogenates were centrifuged at $10000 \mathrm{~g}$ for $30 \mathrm{~min}$ at $4^{\circ} \mathrm{C}$ and the supernatants freeze-dried. The residues were reconstituted in $5 \mathrm{ml}$ distilled water and centrifuged at $10000 \mathrm{~g}$ for $30 \mathrm{~min}$ at $4^{\circ} \mathrm{C}$. Supernatants were assayed immediately or stored at $-20^{\circ} \mathrm{C}$. Tissue extraction recoveries were $65.9 \pm 4.0 \%$.

\section{Radioimmunoassays}

Oxytocin was measured in plasma and corpus luteum extracts by radioimmunoassay (Sheldrick \& Flint, 1981; Flint \& Sheldrick, 1983). Tissue extracts were assayed without further extraction (50 $\mu l$ diluted solution/assay tube); oxytocin was extracted from samples of plasma by mixing with Vycor glass powder, as described previously. The sensitivity, inter- and intra-assay coefficients of variation and extraction efficiency (for Vycor-extracted plasma samples) were $1.8 \mathrm{pg} /$ tube, $16.0 \%$, $12.3 \%$ and $73.3 \pm 1 \cdot 1 \%(n=15)$ respectively. Cross-reactions in the oxytocin assay were: mesotocin ([ $\left.{ }^{8} \mathrm{Ile}\right]$ oxytocin $) 4.1 \%$; isotocin $\left(\left[{ }^{4} \mathrm{Ser},{ }^{8} \mathrm{Ile}\right]\right.$ oxytocin $)<1.0 \%$; lysine vasopressin, arginine vasopressin, $\mathrm{LH}-\mathrm{RH}$, somatostatin, synthetic $\mathrm{C}_{1-24}$ corticotrophin (Synacthen), ovine $\mathrm{LH}$ and ovine prolactin $<0.02 \%$; arginine vasotocin ( $\left[{ }^{8} \mathrm{Arg}\right]$ oxytocin), Pro-Leu-Gly- $\mathrm{NH}_{2}$ (melanocyte hormone inhibitory factor; oxytocin 7-9), and porcine vasoactive intestinal peptide $<0.01 \%$.

Progesterone was measured in plasma by radioimmunoassay as previously reported (Sheldrick, Mitchell \& Flint, 1980). The sensitivity, inter- and intra-assay coefficients of variation and extraction recoveries for the assays reported here were $5 \cdot 2 \mathrm{pg} /$ tube, $7 \cdot 0 \%, 7 \cdot 0 \%$ and $92.9 \pm 1 \cdot 6 \%$, respectively.

\section{Results}

The release of oxytocin from the ovary in response to a luteolytic dose of cloprostenol in intact ewes was absent in animals that had been hysterectomized (Text-figs $2 \mathrm{a} \& \mathrm{~b}$ ). In the first experiment (Text-fig. 2a) ovarian venous plasma concentrations of oxytocin were measured in 4 hysterectomized ewes on Days 53, 56, 76 and 83 after oestrus before and directly after the administration of cloprostenol. The mean ( \pm s.e.m.) progesterone level in these animals was $2.05 \pm 0.15 \mathrm{ng} / \mathrm{ml}$ $(n=12)$ before the administration of cloprostenol. There was no detectable arteriovenous concentration difference for oxytocin across the ovary in hysterectomized ewes either before or after cloprostenol treatment.

When jugular venous concentrations of oxytocin were measured in conscious ewes treated with cloprostenol the rise seen in 4 intact ewes treated on Day 8 of the oestrous cycle was absent in 4 hysterectomized ewes treated on Days $48,78,79$ and 104 after last oestrus (Text-fig. 2b). In this experiment jugular venous progesterone concentrations were $2 \cdot 47 \pm 0 \cdot 29(n=12)$ and $2 \cdot 58 \pm 0 \cdot 24$ $(n=12) \mathrm{ng} / \mathrm{ml}$ for the intact and hysterectomized groups respectively immediately before cloprostenol treatment.

The lack of detectable secretion of oxytocin by the ovary after hysterectomy was reflected in a reduced level of oxytocin in the corpora lutea. In 3 sheep killed on Days 28, 53 and 56 after last oestrus the concentrations of oxytocin in luteal tissue were 11,5 and $7 \mathrm{ng} / \mathrm{g}$ wet weight respectively (compared to $1706 \pm 494 \mathrm{ng} / \mathrm{g}$ in 13 intact ewes on Days $8-14$ of the cycle). The luteal concentration of oxytocin in hysterectomized sheep after cloprostenol treatment was also lower than in intact controls $(4.3 \pm 0.7 \mathrm{ng} / \mathrm{g}$, for hysterectomized ewes between 53 and 83 days after oestrus compared with $39 \pm 16 \mathrm{ng} / \mathrm{g}$ in 5 intact animals between Days 11 and 14 after oestrus; oxytocin measured 40$50 \mathrm{~min}$ after administering $125 \mu \mathrm{g}$ cloprostenol, in both groups).

To determine whether a high concentration of oxytocin in the corpus luteum was required for the luteolytic response to prostaglandin, rates of luteal regression induced by cloprostenol in 3 hysterectomized ewes 78, 79 and 104 days after last oestrus were compared with the response in 4 intact ewes on Day 8 of the cycle (Text-fig. 3). Plasma oxytocin levels in these ewes are included in 


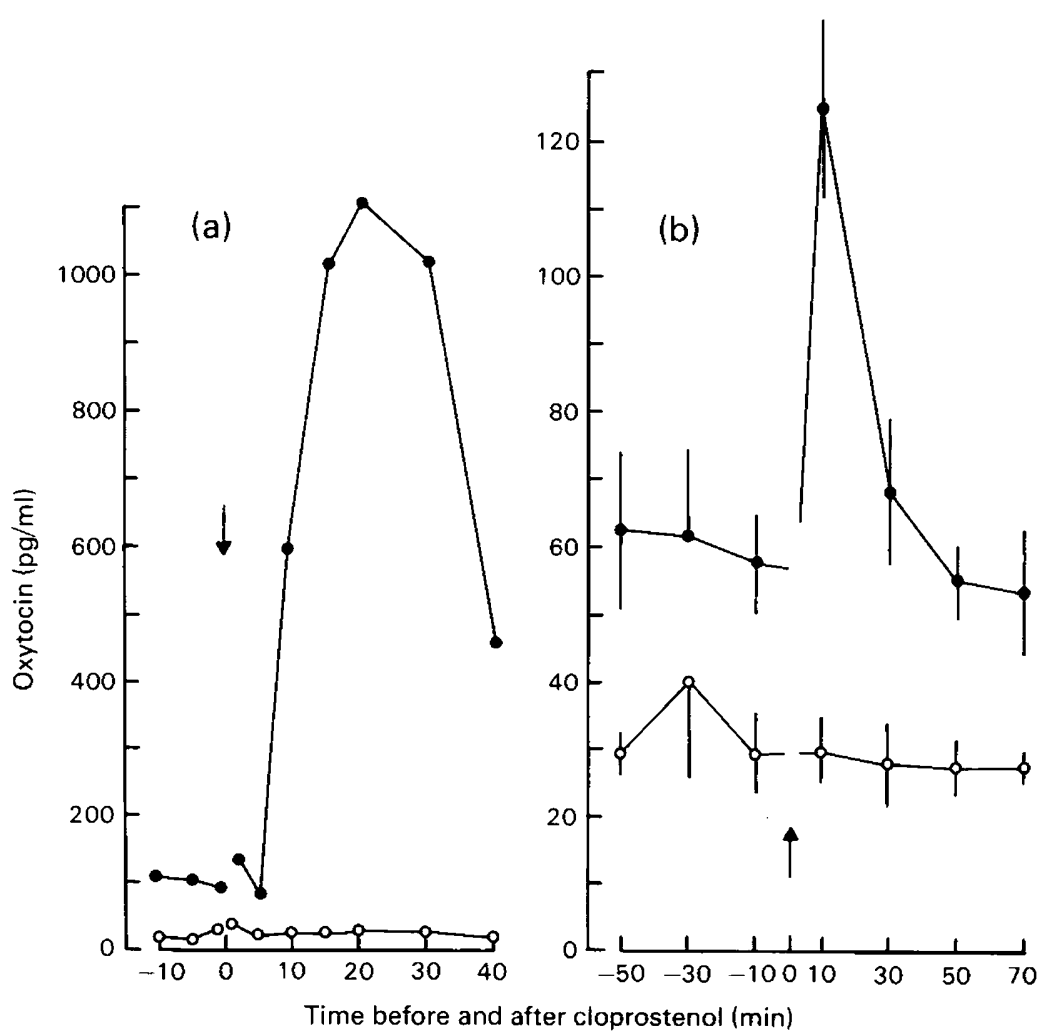

Text-fig. 2. Concentrations (means \pm s.e.m.) of oxytocin in (a) ovarian and (b) jugular venous plasma from sheep treated i.m. with $125 \mu \mathrm{g}$ cloprostenol at $0 \mathrm{~min}$. In (a) 4 hysterectomized ewes anaesthetized with pentobarbitone and halothane in $\mathrm{O}_{2}$ were treated with cloprostenol 53, 56, 76 and 83 days after last oestrus $(O)$; standard errors were less than $20 \%$ of means. Control values $(-)$ from one intact animal on Day 13 after oestrus confirm the response to cloprostenol reported previously (Flint \& Sheldrick, 1982). In (b) 4 intact, non-pregnant ewes received cloprostenol on Day 8 of the oestrous cycle $(-$ ) and 4 hysterectomized ewes were treated 48,78 , 79 and 104 days after last oestrus $(O)$; all animals were conscious.

Text-fig. 2(b). In both groups, jugular venous progesterone concentrations declined rapidly after cloprostenol treatment, reaching basal levels within $24 \mathrm{~h}$ of treatment ; hysterectomy had no significant effect on the rate of luteal regression or the circulating concentration of progesterone before treatment.

\section{Discussion}

The results presented here do not support the hypothesis that one role of ovarian oxytocin is to mediate the luteolytic effect of PGF- $2 \alpha$ in the corpus luteum. Neurohypophysial hormones, in particular arginine vasotocin and vasopressin, reduce rates of gonadotrophin-stimulated steroidogenesis in ovarian and testicular cells in culture (Adashi \& Hsueh, 1981; Tan et al., 1982a, b), but the absence of any effect of hysterectomy on the response to cloprostenol or the basal progesterone secretion rate (as judged by peripheral circulating levels of progesterone) argue against the operation of such a mechanism in the ovine corpus luteum.

This conclusion would not be justified if cloprostenol caused luteal regression by a mechanism different from that by which PGF- $2 \alpha$ acts, or if the dose of cloprostenol used in this study was suffi- 
(a)

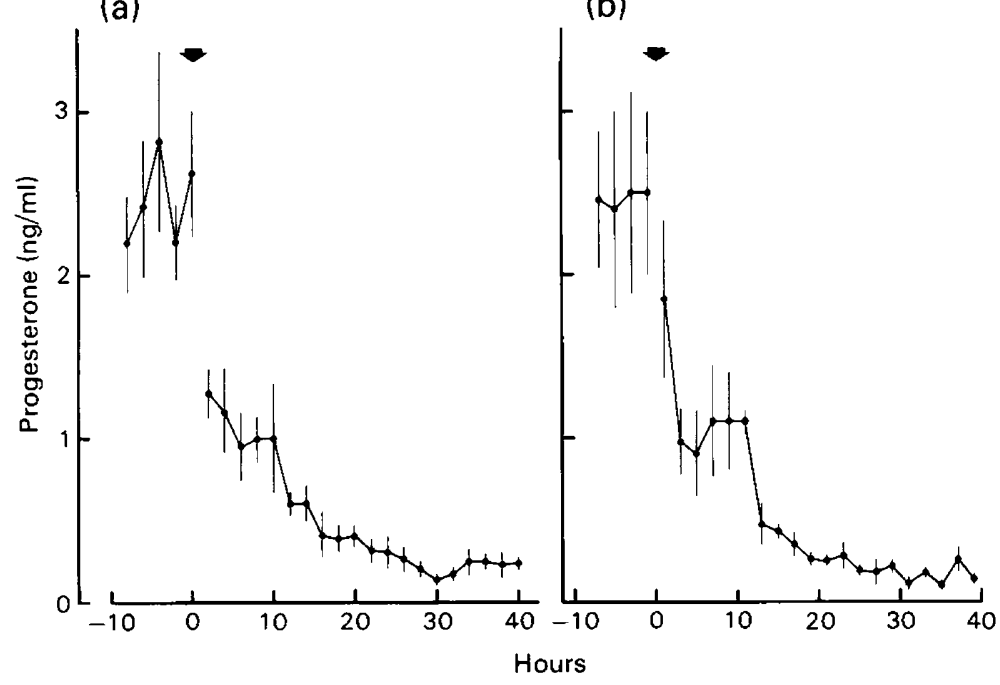

Text-fig. 3. Concentrations of progesterone in (a) intact and (b) hysterectomized ewes treated with cloprostenol (arrow) at $0 \mathrm{~min}$. Intact animals received $125 \mu \mathrm{g}$ cloprostenol i.m. on Day 8 of the cycle $(N=4)$; hysterectomized ewes $(N=3)$ were treated on Days 78,79 and 104 after last oestrus. Values are means; vertical bars indicate s.e.m.

ciently high to exert a non-physiological luteolytic action. However, all available evidence indicates that the actions of the aryloxyprostaglandin $F$ analogues on the corpus luteum mimic those of endogenous or exogenous PGF-2 $\alpha$ both physiologically (Baird \& Scaramuzzi, 1975; Acritopoulou, Haresign, Foster \& Lamming, 1977) and in their inhibitory effects on LH-stimulated adenylate cyclase (Lahov, Freund \& Lindner, 1976; Wakeling \& Green, 1981a). In bovine corpora lutea cloprostenol interacts with the same membrane receptor as native PGF-2 $\alpha$ (Wakeling \& Green, 1981b). Furthermore, the dose of cloprostenol used in this work $(125 \mu \mathrm{g})$ is close to that required to exert a luteolytic action in $100 \%$ of treated animals; Trounson, Willadsen \& Moor (1976) found that $50 \mu \mathrm{g}$ cloprostenol failed to cause consistent returns to oestrus, and Nancarrow, Evison \& Connell (1982) reported that $100 \mu \mathrm{g}$ caused irreversible luteal regression in $94.6 \%$ of ewes treated.

An alternative mechanism by which luteal oxytocin might contribute to luteal regression is via a systemic action involving uterine secretion of PGF- $2 \alpha$, and evidence for such a role has been presented (Flint \& Sheldrick, 1983). Since ovarian blood flow drops at luteal regression (Mattner \& Thorburn, 1969) a third mode of action, through vasoconstriction (Lloyd \& Pickford, 1961), also seems possible.

The reduction in the concentration of oxytocin in the corpus luteum after hysterectomy suggests that luteal synthesis and/or secretion of oxytocin may be influenced by a uterine factor. The absence of any arteriovenous concentration difference for oxytocin across the ovary after hysterectomy indicates that synthesis is more likely to be affected than secretion. If oxytocin is synthesized in the corpus luteum, as it is in the neurohypophysis, in the form of a prohormone (see Richter \& Schmale, 1983), then the effect of hysterectomy may be to change the processing of this precursor, rather than to prevent its synthesis.

\section{References}

Acritopoulou, S., Haresign, W., Foster, J.P. \& Lamming, G.E. (1977) Plasma progesterone and LH concentrations in ewes after injection of an analogue of prostaglandin F-2 $\alpha$. J. Reprod. Fert. 49, 337-340.
Adashi, E.Y. \& Hsueh, A.J.W. (1981) Direct inhibition of testicular androgen biosynthesis revealing antigonadal activity of neurohypophysial hormones. Nature, Lond. 293, 650-652. 
Baird, D.T. \& Scaramuzzi, R.J. (1975) Prostaglandin $F_{2 \alpha}$ and luteal regression in the ewe: comparison with 16aryloxyprostaglandin (I.C.I. 80996). Annls Biol. anim. Biochim. Biophys. 15, 161-174.

Flint, A.P.F. \& Hillier, K. (1975) Prostaglandins and reproductive processes in sheep and goats. In Prostaglandins and Reproduction, pp. 271-308. Ed. S. M. M. Karim. MTP, Lancaster.

Flint, A.P.F. \& Sheldrick, E.L. (1982) Ovarian secretion of oxytocin is stimulated by prostaglandin. Nature, Lond. 297, 587-588.

Flint, A.P.F. \& Sheldrick, E.L. (1983) Evidence for a systemic role for ovarian oxytocin in luteal regression in sheep. J. Reprod. Fert. 67, 215-225.

Lahov, M., Freund, A. \& Lindner, H.R. (1976) Abrogation by prostaglandin $\mathrm{F}_{2 \alpha}$ of $\mathrm{LH}$-stimulated cyclic AMP accumulation in isolated rat corpora lutea of pregnancy. Biochem. Biophys. Res. Commun. 68, 1294-1300.

Lloyd, S. \& Pickford, M. (1961) The action of posterior pituitary hormones on the vascular system of the rat. J. Physiol., Lond. 155, 161-174.

Mattner, P.E. \& Thorburn, G.D. (1969) Ovarian blood flow in sheep during the oestrous cycle. $J$. Reprod. Fert. 19, 547-549.

Nancarrow, C.D., Evison, B.M. \& Connell, P.J. (1982) Effect of embryos on luteolysis and termination of early pregnancy in sheep with cloprostenol. Biol. Reprod. 26, 263-269.

Richter, D. \& Schmale, H. (1983) The structure of the precursor to arginine vasopressin: a model preprohormone. In The Neurohypophysis: Structure, Function and Control (Progr. in Brain Res.), 60, Eds B. A. Cross \& G. Leng. Elsevier, Amsterdam. (In press).
Seldinger, S.I. (1953) Catheter replacement of the needle in percutaneous arteriography. Acta radio. 39, 368376.

Sheldrick, E.L. \& Flint, A.P.F. (1981) Circulating concentrations of oxytocin during the estrous cycle and early pregnancy in sheep. Prostaglandins 22, 631636.

Sheldrick, E.L., Mitchell, M.D. \& Flint, A.P.F. (1980) Delayed luteal regression in ewes immunized against oxytocin. J. Reprod. Fert. 59, 37-42.

Tan, G.J.S., Tweedale, R. \& Biggs, J.S.G. (1982a) Effects of oxytocin on the bovine corpus luteum of early pregnancy. J. Reprod. Fert. 66, 75-78.

Tan, G.J.S., Tweedale, R. \& Biggs, J.S.G. (1982b) Oxytocin may play a role in the control of the human corpus luteum. $J$. Endocr. 95, 65-70.

Trounson, A.O., Willadsen, S.M. \& Moor, R.M. (1976) Effect of prostaglandin analogue Cloprostenol on oestrus, ovulation and embryonic viability in sheep. J. agric. Sci., Camb. 86, 609-611.

Wakeling, A.E. \& Green, L.R. (1981 a) In vitro and in vivo effects of a luteolytic prostaglandin (Estrumate, I.C.I. 80996) on rat ovarian adenylate cyclase activity. Biochem. Soc. Trans. 9, 94-95.

Wakeling, A.E. \& Green, L.R. (1981b) Corpus luteum prostaglandin receptors and luteolysis. Acta vet. Scand., Suppl. 77, 131-142.

Wathes, D.C. \& Swann, R. (1982) Is oxytocin an ovarian hormone? Nature, Lond. 297, 225-227.

Wiltbank, J.N. \& Casida, L.E. (1956) Alteration of ovarian activity by hysterectomy. J. Anim. Sci. 15, 134-140.

Received 6 September 1982 